\title{
A pool of 1,086 words with unique two-letter fragments
}

\author{
JANET M. GIBSON and MICHAEL J. WATKINS \\ Rice University, Houston, Texas
}

\begin{abstract}
Cognitive psychology is finding increasing use for the word fragment completion test, in which words have to be completed from a subset of their letters (e.g., horizon from --r-z--). Researchers often try to restrict their fragments to those that can be completed with only one word, but this is difficult to do and probably never has been achieved. To help resolve this problem, a list is provided of 1,086 three- to eight-letter words, each of which is uniquely specified by a two-letter fragment, where uniqueness is defined on the basis of two sizable word collections.
\end{abstract}

The word fragment completion test is playing an increasingly prominent role in experimental psychology. The test involves the completion of word fragments of the sort that occur in a partly solved crossword puzzle. For example, -- $r-z--$ might be given as a test item for the target word horizon.

The increase in usage of this test is in part an expression of the general liberalization of research methodology that has come with the information processing revolution. A more particular cause is the keen interest that has recently sprung up in the facilitation of word perception that arises when the word is encountered beforehand. A prior encounter with a word has been found to enhance the facility with which it is read (Brooks, 1987; Johnston, Dark, \& Jacoby, 1985; Kolers, 1976), the speed with which it is classified as a word rather than as a nonword (Carroll \& Kirsner, 1982; Feustel, Shiffrin, \& Salasoo, 1983), and the likelihood of its being identified from a tachistoscopic presentation (Jacoby, 1983; Jacoby \& Dallas, 1981). These perceptual priming tests do not inquire whether the words were presented beforehand, and their results have shown perceptual priming even for words whose prior presentations are not recollected (Jacoby \& Witherspoon, 1982; Tulving, Schacter, \& Stark, 1982; Watkins \& Gibson, in press). Although the word fragment procedure is sometimes (e.g., Horowitz, White, \& Atwood, 1968; Nelson \& McEvoy, 1979; Tulving \& Watkins, 1973) used to cue recollection of prior occurrence ("complete the fragment with a word from the list just presented"), it is perhaps more often (e.g., Light, Singh, \& Capps, 1986; Roediger \& Blaxton, 1987; Tulving et al., 1982) used as another test of perceptual priming ("complete the fragment with a word").

The word fragment completion test has the advantage over other perceptual priming tests of being easy to administer. Also, it is a simple matter to create an ordinal scale of fragment completion difficulty. Thus, for a given

This research was supported by National Institute of Mental Health Grant MH35873. Address correspondence to Michael J. Watkins, Department of Psychology, Rice University, Houston, TX 77251. word length, a two-letter fragment (--r-z--) can be assumed to be more difficult to complete than a three-letter fragment (--r-zo-), which in turn can be assumed to be more difficult to complete than a four-letter fragment (-or-zo-), and so on. Although there are bound to be exceptions, such assumptions are likely to hold up in most cases, especially when the letters in the smaller fragments are retained as part of the larger fragments.

The word fragment completion test does, however, have a disadvantage. Unlike test items in other priming tests, a test item in a fragment completion test may allow more than one legitimate response. Such ambiguity may not be critical, but it will add noise. If only one response is allowed for each fragment, then to the extent that nontarget completions are given, the power to detect an effect of, say, prior study or fragment difficulty will be reduced. The problem could be alleviated by requiring as many valid completions as possible, but, because of inhibitory effects of output interference (Roediger, 1974), the problem would not be entirely eliminated. Also, requiring multiple completions might increase the needed response time, and thus decrease the efficiency of the experiment.

It is not surprising, then, that some researchers (e.g., Light et al., 1986; Peynircioglu \& Watkins, 1986; Tulving et al., 1982) have tried to restrict the words they use to ones having unique fragments. In general, this is immensely difficult to do (cf. Erickson, Gaffney, \& Heath, 1987), and finding alternative completions to what researchers claim to be unique cues has developed into something of an underground sport. How can we determine whether, for example, --r-z-- is a fragment that uniquely specifies horizon? If and when we produce an alternative completion, we can be sure the fragment is not unique, but until then we cannot be sure either way.

One easy way of finding fragments that have only one completion is to confine consideration to those whose letters are all from the beginning of the word. These word stem fragments, as they are called, can easily be looked up in a dictionary to determine whether they submit, at least with respect to the entries in that dictionary, to alternative completions. We should note that it is not clear 
whether the way such fragments are completed is similar to the way nonstem fragments are completed (see Graf \& Mandler, 1984; Graf, Squire, \& Mandler, 1984; Greene, 1986; Nelson, Canas, Bajo, \& Keelean, 1987). Also, as a cursory inspection of a dictionary will reveal, the number of such unique fragments is quite limited, at least for the more difficult (one-, two-, or even threeletter) levels.

In short, it would be useful to have for general use a pool of unique fragments unrestricted by letter location. The purpose of this article is to provide such a pool.

\section{Method}

Deriving the pool required a number of decisions. First, it was necessary to decide upon a source vocabulary, a set of words that we could use to operationalize the concept of unique fragment. One obvious possibility is the vocabulary of a regular dictionary. Unfortunately for our purposes, dictionaries typically omit inflectional word forms (e.g., plays, played, playing; taller, tallest), even though they may be highly familiar. Also, most dictionaries include many words that would not be known to the majority of subjects in a typical psychology experiment. Our purposes were better served by a vocabulary based directly on actual usage. Our first choice was the Brown Corpus, which was published originally as Computational Analysis of Present-Day American English (Kučera \& Francis, 1967) and subsequently as Frequency Analysis of English Usage: Lexicon and Grammar (Francis \& Kučera, 1982). Well known to experimental psychologists, the Brown Corpus is a collection of words obtained from 500 writing samples, each of around 2,000 words. The samples represent 15 genres, such as general fiction, romance, science fiction, humor, and religion. The Corpus includes approximately 50,000 different words.

The second decision was whether to include foreign words and proper nouns. On the one hand, such words might well come to mind in a fragment completion test even if, in compliance with instructions, they are not reported. On the other hand, there is likely to be little call for such words, for researchers usually screen them out in selecting their stimuli. We resolved this difficulty by including them when defining uniqueness but excluding them from our listing.

Third, we decided to restrict consideration to words consisting of no more than eight letters. Although longer words are more likely to include a unique fragment, they are seldom used in experimental research.

Our fourth decision concerned fragment size, that is, the number of letters included in the fragment. Small fragments have the advantage that they can be enlarged without endangering their uniqueness, whereas the same cannot be said of cutting down large fragments. For example, if the fragment $--p--b$ is known to be unique, then the fragments $--p e-b,-u p e-b$, and supe- $b$ must also be unique; however, if $p$-etry is known to be unique, we cannot be sure that $p-e t-y, p-e--y$, or $p-e---$ is unique. Of course, the num- ber of words with a unique $n$-letter fragment diminishes dramatically as $n$ is reduced, and for a word pool to be useful it should be large enough to allow selection for frequency of usage, length, and other variables. A preliminary search turned up only a handful of words with unique one-letter fragments, and so we conducted a search for words with unique two-letter fragments.

With the specifications set, a computer search was conducted on tapes of the Francis and Kucera (1982) description of the Corpus. ${ }^{1}$ Some words were found to have more than one unique fragment (e.g., galaxy is uniquely specified by $g---x-,-a--x-,--l a--,---a x-$, and ----xy); in these cases one fragment was selected at random. A casual inspection of the resulting pool revealed two problems. First, a nontrivial proportion of the fragments had alternative completions by words that are not included in the Corpus but are likely to be in the vocabulary of most subjects. For example, $-x-u--$ could be completed by exhume as well as by excuse, and gn-- by gnaw as well as by gnat. Second, and more conspicuously, quite a few of the words could reasonably be regarded as peculiar to the Corpus; some extreme examples are sssshoo, whaddya, yehhh, and zoooop. The alleviation of these two problems posed something of a dilemma: Reducing the number of fragments that would submit to an alternative completion required that the source vocabulary be increased, but reducing the number of "words" that were too rare to be of much interest to experimental psychologists required that it be decreased. To resolve this dilemma, we introduced a second source vocabulary, and defined a fragment as unique if it could be completed by only one word from either vocabulary, but included a word in our listing only if it occurred in both vocabularies. (We were able to retain a few of the words with fragments that could be completed by an alternative word from the second source by substituting what the computer search had designated as an alternative unique fragment.) By adopting two different criteria in this way, we reduced both the likelihood that our fragments would yield a legitimate unintended completion and the likelihood of listing a word that is too rare to be of use.

The second source vocabulary was the Puzzle Solver's Handbook (Corron, 1970), a collection of 18,003 words, ranging from two to eight letters in length. The book was sold by mail order as an aid in the solution of crossword puzzles. Although rarely cited, it has, to our knowledge, been used in more than one laboratory in which word completion research is conducted. The words are sorted by length, and within each length they are printed as many times as there are letters in the words, first alphabetically according to their first letters, second according to their second letters, and so on. This arrangement facilitates checking for fragment uniqueness. One of its shortcomings is its omission of many inflectional word forms. We therefore removed from our list as many words as we could find-and doubtless there were some we missedwith fragments that could also be completed by another 
form of the same root word, provided the root word was included in the Puzzle Solver's Handbook.

As a final measure to reduce the number of fragments with a nontrivial chance of being given an alternative completion, we paid 12 graduate students from the psychology department of Rice University to try to complete the 1,203 word fragments that had survived until this stage. They were to spend approximately $6 \mathrm{sec}$ on each, and were told that, although the task was so difficult they would not be able to think of even one completion for many of the fragments, if on occasion they thought of two completions they should write down both. A total of 117 fragments yielded legitimate alternative completions, and these fragments were discarded from the pool, leaving 1,086 in the final version. Note that we can give no guarantee that the fragments of the final pool will not produce unintended completions that happened not to be listed in either the Brown Corpus or the Puzzle Solver's Handbook and were not generated by our 12 reviewers. Of course, the probability of a legitimate alternative completion will reduce rapidly as the fragment size is increased by addition of more letters.

To summarize, each of the words listed in the Appendix (1) includes a two-letter fragment that, with place markers for the other letters, does not fit any other word from either the Brown Corpus or the Puzzle Solver's Handbook and was not given an alternative completion by any of 12 reviewers; (2) occurs in both the Brown Corpus and the Puzzle Solver's Handbook; (3) is not, according to Francis and Kucera (1982), exclusively a proper noun or foreign word; and (4) consists of no more than eight letters. The listing does not include two-letter words because these are, of course, all uniquely specified by two letters. The list comprises 1,086 words: 75 of three letters, 98 of four letters, 146 of five letters, 203 of six letters, 261 of seven letters, and 303 of eight letters. They are organized first by length and then alphabetically within each length. The two letters that, with place markers for the others, uniquely define the word are enlarged. Thus, $-b-n---$ is a unique fragment for abandon. Each word is followed by a number, which specifies the frequency with which the word occurred in the approximately onemillion-word count of the Brown Corpus, as given in the Kučera and Francis (1967) listing.

\section{REFERENCES}

Brooks, J. O., III. (1987). Enhancing and degrading visual stimuli. Behavior Research Methods, Instruments, \& Computers, 19, 260-269.

Carroll, M., Kirsner, K. (1982). Context and repetition effects in lexical decision and recognition memory. Journal of Verbal Learning \& Verbal Behavior, 21, 55-69.

Corron, D. R. (1970). Puzzle solver's handbook. Tucson, AZ: Author.

Eruckson, J. R., GaFfney, C. R. , Heath, W. P. (1987). Difficulty and familiarity norms for 192 single-solution word fragments. Behavior Research Methods, Instruments, \& Computers, 19, 370-376.
Feustel, T. C., Shiffrin, R. M., * Salasoo, A. (1983). Episodic and lexical contributions to the repetition effect in word identification. Journal of Experimental Psychology, 112, 306-346.

FrANCIS, W. N., KuČERA, H. (1982). Frequency analysis of English usage: Lexicon and grammar. Boston: Houghton Mifflin.

GraF, P., \& MANDler, G. (1984). Activation makes words more accessible, but not necessarily more retrievable. Joumal of Verbal Learning \& Verbal Behavior, 23, 553-568.

Graf, P., SQuire, L. R., MANDler, G. (1984). The information that amnesic patients do not forget. Journal of Experimental Psychology: Learning, Memory, \& Cognition, 10, 164-178.

GREENE, R. L. (1986). Word stems as cues in recall and completion tasks. The Quarterly Journal of Experimental Psychology, 38A, 663-673.

Horowitz, L. M., White, M. A., \& ATwood, D. W. (1968). Word fragments as aids to recall: The organization of a word. Journal of Experimental Psychology, 76, 219-220.

JACOBY, L. L. (1983). Perceptual enhancement: Persistent effects of an experience. Journal of Experimental Psychology: Learning, Memory, \& Cognition, 9, 21-38.

JACOBY, L. L., \& DAllas, M. (1981). On the relationship between autobiographical memory and perceptual learning. Journal of Experimental Psychology: General, 110, 306-340.

JACOBY, L. L., \& WITHERSPOON, D. (1982). Remembering without awareness. Canadian Journal of Psychology, 36, 300-324.

Johnston, W., DARK, V., \& JACOBY, L. L. (1985). Perceptual fluency and recognition judgments. Journal of Experimental Psychology: Learning, Memory, \& Cognition, 11, 3-11.

Kolers, P. (1976). Reading a year later. Journal of Experimental Psychology: Human Learning \& Memory, 2, 554-564.

KuČERA, H., \& FrANCIS, W. N. (1967). Compuctational analysis of presentday American English. Providence, RI: Brown University Press.

Light, L., Singh, A., CAPPS, J. (1986). Dissociation of memory and awareness in young and older adults. Journal of Clinical \& Experimental Neuropsychology, 8, 62-74.

Nelson, D. L., Canas, J. J., Bajo, M. T., Keglean, P. D. (1987). Comparing word fragment completion and cued recall with letter cues. Journal of Experimental Psychology: Learning, Memory, \& Cognition, 13, 542-552.

Nelson, D. L., \& McEvoy, C. L. (1979). Encoding context and set size. Journal of-Experimental Psychology: Human Learning \& Memory, 5, 292-314.

Peynircioglu, Z. F., Watkins, M. J. (1986). Cue depreciation: When word fragment completion is undermined by prior exposure to lesser fragments. Journal of Experimental Psychology: Learning, Memory, \& Cognition, 12, 426-431.

RoEDIGER, H. L. (1974). Inhibitory effects of recall. Memory \& $\mathrm{Cog}$ nition, 2, 261-296.

Roediger, H. L., BlaXton, T. A. (1987). Effects of varying modality, surface features, and retention interval on priming in wordfragment completion. Memory \& Cognition, 15, 379-388.

Tulving, E., Schacter, D. L., Stark, H. A. (1982). Priming effects in word-fragment completion are independent of recognition memory. Journal of Experimental Psychology: Learning, Memory, \& Cognition, 8, 336-342.

Tulving, E., W Wtikins, M. J. (1973). Continuity between recall and recognition. American Journal of Psychology, 86, 739-748.

WatkINS, M. J., GIBson, J. M. (in press). On the relation between perceptual priming and recognition memory. Joumal of Experimental Psychology: Learning, Memory, \& Cognition.

\section{NOTE}

1. Words and word fragments used in this study have been selected, with permission, on the basis of information that was provided by W. Nelson Francis, Henry Kucera, and Houghton Mifflin Company and that appears in part in Frequency Analysis of English Usage: Lexicon and Grammar by W. Nelson Francis and Henry Kưera, 1982. Copyright 1982 by Houghton Mifflin Company. 
APPENDIX

Words with Unique Two-Letter Fragments

Fragment uniqueness is defined on the basis of words that occur in the Brown Corpus (Francis \& Kucera, 1982) or the Puzzle Solver's Handbook (Corron, 1970) or both; the unique fragment is indicated by enlarged letters. The words are arranged by length and alphabetically within length. The numbers refer to frequency of occurrence in the $1,014,232$-word Brown Corpus. Additional details are given in the text.

Three-letter words

$\begin{array}{lllllll}\text { ACT 283 } & \text { ADO 4 } & \text { AFT 5 } & \text { AGE 227 } & \text { AIR 257 } & \text { ANY 1345 } & \text { ARC 41 } \\ \text { ARM 94 } & \text { ASK 128 } & \text { ASS 5 } & \text { ATE 16 } & \text { AXE 6 } & \text { BOO 1 } & \text { BOW 15 } \\ \text { BYE 2 } & \text { CRY 48 } & \text { DRY 68 } & \text { EBB 1 } & \text { EEL 2 } & \text { EGG 12 } & \text { EGO 13 } \\ \text { ELK 1 } & \text { ELM 3 } & \text { END 10 } & \text { ERR 1 } & \text { FEW 601 } & \text { FLU 8 } & \text { HEX 2 } \\ \text { ICY 12 } & \text { ILL 39 } & \text { INK 7 } & \text { ION 6 } & \text { ITS 1858 } & \text { IVY 9 } & \text { KEG 2 } \\ \text { KID 61 } & \text { KIT 2 } & \text { MAY 1400 } & \text { MOB 10 } & \text { NAY 2 } & \text { NIL 1 } & \text { NOD 12 } \\ \text { OAK 15 } & \text { OIL 93 } & \text { OLD 660 } & \text { ONE 3292 } & \text { ORB 1 } & \text { OVA 1 } & \text { OWN 772 } \\ \text { PRO 16 } & \text { PUB 1 } & \text { REV 33 } & \text { RYE 4 } & \text { SAG 4 } & \text { SKI 5 } & \text { SKY 58 } \\ \text { SLY 5 } & \text { SPA 2 } & \text { SPY 9 } & \text { TEA 28 } & \text { TRY 140 } & \text { TWO 1412 } & \text { URN 2 } \\ \text { USE 589 } & \text { VIA 48 } & \text { VOW 2 } & \text { WAR 464 } & \text { WAX 14 } & \text { WEB 6 } & \text { WRY 5 } \\ \text { YEA 3 } & \text { YES 144 } & \text { YET 419 } & \text { YOU 3286 } & \text { ZOO 9 } & & \end{array}$

Four-letter words

$\begin{array}{lllllll}\text { ACID 13 } & \text { AFAR 2 } & \text { AGED 18 } & \text { AGUE 1 } & \text { AJAR 2 } & \text { AKIN 10 } & \text { ALTO 4 } \\ \text { AMID 14 } & \text { AMMO 4 } & \text { ANTI 1 } & \text { APEX 4 } & \text { ARCH 13 } & \text { ASKS 18 } & \text { ATOP 6 } \\ \text { AVID 1 } & \text { AWRY 2 } & \text { AXLE 5 } & \text { BLOC 10 } & \text { BUFF 5 } & \text { BUZZ 13 } & \text { CASH 36 } \\ \text { CHEF 9 } & \text { CHIC 7 } & \text { COZY 1 } & \text { CZAR 1 } & \text { DAYS 384 } & \text { DEBT 13 } & \text { DISC 6 } \\ \text { EATs 3 } & \text { ECHO 10 } & \text { EDIT 2 } & \text { EGGS 35 } & \text { ENVY 7 } & \text { ERRS 1 } & \text { EXIT 7 } \\ \text { FISH 35 } & \text { FIVE 286 } & \text { HERB 7 } & \text { JAZZ 99 } & \text { JINX 1 } & \text { JOYS 7 } & \text { KEGS 1 } \\ \text { KEYS 34 } & \text { KHAN 2 } & \text { KIDS 32 } & \text { KISS 17 } & \text { LAYS 6 } & \text { MOVE 171 } & \text { MYTH 35 } \\ \text { NEXT 394 } & \text { NORM 10 } & \text { NOUN 1 } & \text { NUMB 4 } & \text { OAFs 1 } & \text { OAKS 1 } & \text { OKAY 20 } \\ \text { ONLY 1747 } & \text { OWLS 2 } & \text { PAVE 2 } & \text { PAYS 17 } & \text { PUFF 1 } & \text { PYRE 1 } & \text { QUT 15 } \\ \text { QUZ 2 } & \text { RAKE 11 } & \text { RARE 41 } & \text { RAYS 9 } & \text { SIGN 94 } & \text { SKIP 5 } & \text { SKIS 1 } \\ \text { SKIT 1 } & \text { STAG 8 } & \text { STAY 113 } & \text { STUD 7 } & \text { SWAP 2 } & \text { SWUM 1 } & \text { TOYS 11 } \\ \text { UGLY 21 } & \text { UNT 103 } & \text { UNTo 16 } & \text { UPON 495 } & \text { UREA 1 } & \text { URGE 21 } & \text { URNS 2 } \\ \text { USED 612 } & \text { VAMP 1 } & \text { VERB 4 } & \text { VIEW 186 } & \text { VOWS 5 } & \text { WAXY 2 } & \text { WHIZ 2 } \\ \text { WOMB 1 } & \text { YARD 35 } & \text { YELP 2 } & \text { YOUR 923 } & \text { ZEAL 8 } & \text { ZERO 24 } & \text { ZINC 10 }\end{array}$

Five-letter words

$\begin{array}{llllll}\text { ABACK } 2 & \text { ABIDE } 7 & \text { ABOUT 1815 } & \text { ABOVE 296 } & \text { ACIDS 7 } & \text { ADAGE 3 } \\ \text { ADOBE 2 } & \text { AFFIX 1 } & \text { AFIRE 1 } & \text { AFOOT 1 } & \text { AGENT 44 } & \text { AGING 4 } \\ \text { AGONY 9 } & \text { ALBUM 6 } & \text { ALIBI 8 } & \text { AMAZE 3 } & \text { AMONG 370 } & \text { ANKLE 8 } \\ \text { ANNEX 1 } & \text { ANTIC 1 } & \text { AORTA 3 } & \text { ASIDE 67 } & \text { ASKED 398 } & \text { ASKEW 1 } \\ \text { AVAIL 4 } & \text { AWFUL 17 } & \text { AXIAL 2 } & \text { AXIOM 1 } & \text { BANJO 2 } & \text { BUOYS 1 } \\ \text { CHAOS 17 } & \text { CLIMB 12 } & \text { COZEN 1 } & \text { CROWD 53 } & \text { DEBTS 12 } & \text { DEPTH 53 } \\ \text { DIZZY 5 } & \text { DOUBT 114 } & \text { DROOP 1 } & \text { DWARF 3 } & \text { EBONY 3 } & \text { ECLAT 1 }\end{array}$


APPENDIX (Continued)

\begin{tabular}{|c|c|c|c|c|c|}
\hline EERIE 2 & EIGHT 104 & EJECT 1 & ELFIN 1 & EMCEE 1 & ENDOW 2 \\
\hline ENJOY 44 & EPOCH 6 & EQUAL 90 & ETHYL 4 & EVADE 1 & EvoKE 6 \\
\hline ЕХАCT 27 & EXCEL 1 & EXERT 11 & EXIST 59 & EXITs 1 & EXPEL 2 \\
\hline EXTRA 50 & EYING 2 & FLUFF 1 & FLUKE 1 & FRANC 1 & GREEK 61 \\
\hline GYPSY 4 & HaVoC 3 & HIGHs 2 & INDEX 81 & IRATE 1 & IRISH 28 \\
\hline ISsUE 152 & JAZZY 1 & JEANS 1 & JIFFY 2 & JIMMY 11 & KHAKI 1 \\
\hline KICKS 3 & LATEX 2 & MAUVE 1 & MAYBE 134 & MotIF 8 & MYRRH 2 \\
\hline oBEYS 1 & oFFAL 1 & oFTEN 368 & OHMIC 1 & OLIVE 5 & OUNCE 3 \\
\hline OUTDo 3 & OWING 3 & oZONE 3 & PIQUE 2 & PLUMB 5 & PSALM 4 \\
\hline QUAKE 2 & QUEER 6 & QUERY 1 & QuOTA 4 & RABBI 13 & RADII 4 \\
\hline RAJAH 1 & RELAX 19 & RENEW 4 & RIFLE 63 & SCREW 21 & SCRUB 9 \\
\hline SEIZE 6 & SHEIK 4 & SHRUG 2 & SIEVE 1 & SIXTH 26 & SKIFF 9 \\
\hline SKIPS 5 & SKIRT 21 & SLYLY 2 & SPASM 3 & sPooF 1 & SPUME 1 \\
\hline SQUAT 7 & sQUAW 1 & sWARM 3 & sWIFT 32 & sWUNG 48 & SYRUP 4 \\
\hline TOXIC 3 & TWICE 74 & ULCER 5 & UNIFY 2 & USAGE 14 & UsHER 2 \\
\hline USING 145 & USUAL 96 & VERBS 7 & VIEWS 51 & VINYL 4 & VYING 3 \\
\hline WIDTH 14 & XENON 1 & XYLEM 4 & YEAST 3 & YOUNG 385 & YuCCA 1 \\
\hline ZEBRA 1 & ZEROS 2 & & & & \\
\hline \multicolumn{6}{|l|}{ Six-letter words } \\
\hline ABLAZE 3 & ABROAD 51 & ABRUPT 18 & ABSORB 13 & ADHERE 4 & ADRIFT 1 \\
\hline ADVERB 1 & AFFAIR 33 & AFFIRM 12 & AFGHAN 3 & AFIELD 1 & AFLAME 3 \\
\hline AGENCY 56 & AGENDA 5 & AGHAST 1 & AGLEAM 1 & AGREED 81 & ALBUMS 2 \\
\hline ALKALI 4 & ALUMNI 9 & ALWAYS 458 & ANSWER 44 & APLOMB 1 & ARRoWs 6 \\
\hline ASKING 67 & ASLEEP 29 & ASsiGN 18 & ASTHMA 1 & AVENGE 2 & AVENUE 46 \\
\hline AVIARY 1 & AXIOMS 2 & AZALEA 2 & BAZAAR 7 & BEHALF 21 & BEHAVE 13 \\
\hline BOGEYS 2 & BOXCAR 6 & BUREAU 43 & CATKIN 2 & CLIMAX 14 & COGNAC 4 \\
\hline COWBOY 16 & CROWDS 12 & CUPFUL 3 & CuTOFF 1 & DAYBED 1 & DELUXE 2 \\
\hline DEPTHS 19 & DISOWN 1 & DREAMT 1 & DUPLEX 1 & DWARFs 2 & DYNAMO 2 \\
\hline EDITOR 77 & EIGHTH 23 & ELBoWs 7 & ELEVEN 40 & EMBRYO 1 & ENDOWs 1 \\
\hline ENGAGE 14 & ENJOYs 10 & ENZYME 6 & EQUITY 7 & ESCHEW 1 & ETHNIC 13 \\
\hline EVoLVE 5 & EXEMPT 5 & EXISTS 42 & EXodUs 4 & EXoTIC 7 & EXPECT 108 \\
\hline EXTRAs 1 & FILLIP 1 & FOLKSY 3 & FORAYS 1 & GADFLY 3 & GALAXY 3 \\
\hline GROWTH 155 & HEREBY 8 & HEROIC 21 & HOMAGE 2 & HYBRID 1 & ICEBOX 3 \\
\hline ICICLE 1 & IDIoMs 3 & IMBIBE 1 & INDIGO 1 & INFLOW 2 & INFLUX 4 \\
\hline INJURY 27 & INWARD 9 & IODIDE 8 & ITSELF 304 & JOYFUL 1 & LAWFUL 2 \\
\hline LEGUME 2 & LENGTH 116 & LIQUOR 43 & LUMMOX 1 & MATRIX 1 & MILIEU 4 \\
\hline MOSAIC 4 & MOTIVE 22 & NATIVE 46 & NEARBY 44 & NoTIFy 8 & NUTMEG 4 \\
\hline NYMPHS 1 & oBEYED 7 & OBLIGE 1 & OBOIST 1 & OBTAIN 42 & OCCUPY 16 \\
\hline oDioUs 3 & OFFERS 45 & OFFSET 9 & OMELET 3 & OPAQUE 6 & OssIFY 1 \\
\hline OTHERS 323 & OUTFOX 1 & OUTLAW 2 & OUTPuT 35 & OUTWIT 1 & OXIDES 1 \\
\hline OXYGEN 43 & PAYOFF 1 & PIAZZA 17 & PICNIC 15 & PlaQue 2 & PREFAB 1 \\
\hline PUZZLE 10 & PYTHON 14 & QUAINT 12 & QUALMS 1 & QUARTZ 1 & RAKISH 1 \\
\hline REBUFF 4 & REBUKE 2 & REMOVE 58 & REVIEW 56 & REVIVE 8 & REVVED 1 \\
\hline RHYTHM 22 & RUNOFF 2 & RUNWAY 4 & SCHISM 1 & SEQUEL 1 & SEWAGE 29 \\
\hline SEXTET 4 & SHADOW 36 & SHREWD 8 & SKETCH 16 & SKIRTS 4 & SMACKS 1 \\
\hline
\end{tabular}


APPENDIX (Continued)

\begin{tabular}{llllll}
\hline SPRAYS 1 & SPYING 2 & SQUASH 2 & STAYED 75 & STRAYS 6 & STUCCO 4 \\
SUPERB 14 & SVELTE 1 & SWARMS 1 & SWIVEL 5 & SYNTAX 6 & TALLOW 1 \\
TAVERN 2 & TAXIED 1 & THUMBS 3 & THWACK 1 & TORQUE 5 & TRAGIC 33 \\
UNEVEN 6 & UNIQUE 58 & UNJUST 3 & UNKIND 3 & UPBEAT 1 & UPDATE 1 \\
UPKEEP 6 & UPSHOT 1 & UPTOWN 5 & USABLE 8 & USAGES 3 & USEFUL 58 \\
UTMOST 7 & UTOPIA 24 & VACUUM 20 & VANISH 5 & VEERED 3 & VIVIFY 1 \\
VOTIVE 2 & WARMTH 28 & WIDTHS 5 & WINNOW 1 & WISDOM 44 & YACHTS 3 \\
YONDER 1 & YOUTHS 11 & ZEALOT 1 & ZOMBIE 1 & ZOUNDS 2 &
\end{tabular}

Seven-letter words

\begin{tabular}{|c|c|c|c|}
\hline ABANDON 17 & ABOLISH 8 & ABOUNDS 1 & ABREAST 5 \\
\hline ABSORBS 1 & ABYSMAL 2 & ACHIEVE 51 & ACOLYTE 1 \\
\hline ADJUNCT 6 & ADRENAL 2 & ADSORBS 1 & ADVERBS 2 \\
\hline AFFRONT 2 & AFrICAN 28 & AGAINST 626 & ALCOHOL 13 \\
\hline AMONGST 4 & AMPLIFY 1 & ANALYST 7 & ANTIQUE 12 \\
\hline APROPOS 1 & AQUEOUS 14 & ARCHAIC 5 & ARMHOLE 3 \\
\hline ASCRIBE 1 & ASEPTIC 1 & ASKANCE 1 & ASPECTS 64 \\
\hline ASUNDER 1 & ATHLETE 9 & AVIATOR 3 & AVOCADO 11 \\
\hline AWKWARD 11 & AWNINGs 2 & BAGPIPE 1 & BATHTUB 4 \\
\hline BENEFIT 63 & BEQUEST 5 & BETRAYS 3 & BICYCLE 5 \\
\hline BRAVURA 1 & BREADTH 7 & BUFFALO 16 & CADENZA 3 \\
\hline CARAWAY 2 & CASHEWS 1 & СНАОТТС 5 & CITIZEN 1 \\
\hline COBWEBS 1 & CONTEXT 35 & COWBOYs 4 & CZARINA 2 \\
\hline DISGUST 1 & DISROBE 1 & DISTURB 10 & DOORWAY 15 \\
\hline ECHOING 2 & ECSTASY 6 & EDITING 5 & EDUCATE 7 \\
\hline EGoTISM 3 & EJECTED 2 & ELEGIAC 2 & ELUSIVE 2 \\
\hline EMPOWER 1 & ENZYMES 11 & EPITOME 2 & ESCHEWS 1 \\
\hline EVINCED 1 & EXCERPT 6 & EXCLAIM 1 & EXISTED 40 \\
\hline EXPLAIN 64 & EXPLORE 12 & EXPUNGE 1 & EYEBROW 4 \\
\hline FORSAKE 1 & FRANTIC 11 & FRIDAYs 3 & FUCHSIA 1 \\
\hline GODLIKE 1 & GROWTHS 1 & GUFFAWS 1 & HACKSAW 1 \\
\hline HALFWAY 18 & HEBRAIC 1 & HELPFUL 29 & HEXAGON 1 \\
\hline HIGHWAY 40 & HIMSELF 603 & HOPEFUL 12 & HORIZON 27 \\
\hline HYDROUS 1 & IDOLZZE 1 & IDYLLIC 4 & IGNEOUS 1 \\
\hline IMPROVE 39 & INEXACT 2 & INFIDEL 1 & INSIGHT 22 \\
\hline IRKSOME 1 & ISOMERS 1 & ISRAELI 4 & ISSUING 4 \\
\hline JUSTIFY 26 & KICKOFF 2 & KIDNEYS 5 & KINDRED 3 \\
\hline KINGDOM 26 & KINGPIN 1 & KNUCKLE 3 & LACKEYS 1 \\
\hline LAWYERS 23 & LAYOFFS 1 & LEISURE 11 & LIQUEUR 1 \\
\hline MAJESTY 1 & MARVELS 1 & MAWKISH 1 & MAXIMUM 79 \\
\hline MIDWIFE 1 & MODICuM 2 & MOVABLE 19 & MYstiCs 3 \\
\hline NEWSBOY 2 & NONSTOP 1 & NULLIFY 1 & OBELISK 6 \\
\hline ODYSSEY 11 & OFFBEAT 1 & OFFHAND 1 & ONESELF 5 \\
\hline ORGASMS 1 & OUTLAYS 1 & OVATION 2 & OXYGENS 3 \\
\hline PARADOX 9 & PERFUME 10 & PERJURY 3 & PFENNIG 1 \\
\hline PIQUANT 2 & PLATEAU 3 & PLAYFUL 3 & POLYMER 1 \\
\hline
\end{tabular}

ABSENCE 53
ADDICTS 4
AFFIMS 1
ALLEGRO 2
APPROVE 14
ARRAYED 2
ASSIGNS 4
AWFULLY 10
BEDTIME 4
BIVOUAC 5
CALYPSO 1
COAXING 1
DEFYING 2
DOWAGER 1
EGGHEAD 1
EMBARGO 2
EVASIVE 5
EXPECTS 22
FILMDOM 1
GAZETTE 10
HALCYON 1
HIGHBOY 1
HUZZAHS 1
IMPACTS 3
INSIPID 1
JOYRIDE 2
KINETIC 8
LACQUER 2
LQUDDS 6
MAZURKA 2
NEPHEWS 5
OBSCURE 17
ONWARDS 1
PAPRIKA 2
PIGSKIN 1
PRETEXT 3


APPENDIX (Continued)

$\begin{array}{lllll}\text { PREVIEW 1 } & \text { PROJECT 93 } & \text { PROVERB 5 } & \text { PROVOKE 3 } & \text { PSYCHIC } 3 \\ \text { QUALIFY 15 } & \text { QUBBBLE 1 } & \text { QUICKEN 1 } & \text { RAINBOW 4 } & \text { REDCOAT 6 } \\ \text { REFUGEE 7 } & \text { RELAYED 2 } & \text { REMARKS 53 } & \text { RENEWAL 8 } & \text { REPROOF 1 } \\ \text { REVIEWS 9 } & \text { ROOFTOP 2 } & \text { ROUNDUP 3 } & \text { RUNAWAY 6 } & \text { RUNWAYS 4 } \\ \text { SATISFY 16 } & \text { SAWMILL 1 } & \text { SAYINGS 1 } & \text { SCARIFY 1 } & \text { SCRAWNY 4 } \\ \text { SHERIFF 20 } & \text { SHRINKS 2 } & \text { SKILFUL 1 } & \text { SOJOURN 5 } & \text { SOMEHOW 72 } \\ \text { SPEEDUP 1 } & \text { SQUEEZE 11 } & \text { STANDBY 3 } & \text { STAYING 17 } & \text { STIMULI 5 } \\ \text { STYLISH 2 } & \text { SUBMITS 3 } & \text { SUBWAYS 1 } & \text { SUCCUMB 1 } & \text { SURVIVE } 33 \\ \text { SWALLOW 10 } & \text { SWARTHY 4 } & \text { SWIVELS 1 } & \text { SYMPTOM 5 } & \text { TABLEAU 1 } \\ \text { TAFFETA 2 } & \text { TAKEOFF 1 } & \text { TALLYHO 7 } & \text { TAXICAB 1 } & \text { TRAFFIC 68 } \\ \text { TRAMWAY 1 } & \text { TRIUMPH 22 } & \text { TURNIPS 1 } & \text { TWELFTH 5 } & \text { TWINKLE } 3 \\ \text { UNDERGO 8 } & \text { UNDYING 1 } & \text { UNEQUAL 1 } & \text { UNHAPPY 26 } & \text { UNKEMPT 1 } \\ \text { UNKNOWN 47 } & \text { UNLOCKS 2 } & \text { UNSCREW 1 } & \text { UPGRADE 3 } & \text { UPRIGHT 14 } \\ \text { UPWARDS 6 } & \text { URANIUM 6 } & \text { URETHRA 1 } & \text { VALLEYS 5 } & \text { VAQUERO 1 } \\ \text { VARYING 42 } & \text { VEHICLE 35 } & \text { VENISON 1 } & \text { WAKEFUL 5 } & \text { WALNUTS } 5 \\ \text { WARLIKE 5 } & \text { WAYSIDE 2 } & \text { WROUGHT 3 } & \text { YAWNING 2 } & \text { YIDDISH 4 } \\ \text { ZOOMING 1 } & & & & \end{array}$

Eight-letter words

$\begin{array}{lll}\text { ABEYANCE } 3 & \text { ABNORMAL 3 } & \text { ABSINTHE 1 } \\ \text { ADEQUACY 3 } & \text { ADJOINED 2 } & \text { ADJOURNS 1 } \\ \text { AFFORDED 11 } & \text { AGENCIES 62 } & \text { AGRARIAN 8 } \\ \text { AIRSTRIP 2 } & \text { ALCOHOLS 2 } & \text { ALFRESCO 2 } \\ \text { ANECDOTE 9 } & \text { ANTIQUES 3 } & \text { APPENDIX 10 } \\ \text { ASBESTOS 1 } & \text { ATHEISTS 3 } & \text { BABYHOOD 1 } \\ \text { BAPTISMS 1 } & \text { BEAUTIFY 1 } & \text { BELLBOYS 4 } \\ \text { BLIZZARD 7 } & \text { BOOMTOWN 1 } & \text { BOUQUETS 1 } \\ \text { BULLDOZE 1 } & \text { BUNGALOW 1 } & \text { CHERUBIM 1 } \\ \text { CLASSIFY 6 } & \text { CLEAVAGE 2 } & \text { CLIMAXED 2 } \\ \text { COLLOQUY 1 } & \text { COMFORTS 5 } & \text { CONDEMNS 3 } \\ \text { CONTEXTS 2 } & \text { CONTRIVE 1 } & \text { CONVULSE 3 } \\ \text { CYLINDER 18 } & \text { DESCRIBE 41 } & \text { DEWDROPS 1 } \\ \text { DISMAYED 1 } & \text { DISPLAYS 21 } & \text { DISRUPTS 1 } \\ \text { DOORKNOB 3 } & \text { DOWNBEAT 1 } & \text { DOWNCAST 2 } \\ \text { DRAWBACK 2 } & \text { DREADFUL 10 } & \text { DRIVEWAY 14 } \\ \text { EGGSHELL 1 } & \text { EGYPTIAN 5 } & \text { ELBOWING 1 } \\ \text { EMBEZZLE 1 } & \text { EMERALDS 6 } & \text { EPIGRAMS 2 } \\ \text { EQUATING 1 } & \text { ESSENCES 2 } & \text { EUPHORIA 2 } \\ \text { EVER YDAY 12 } & \text { EVIDENCE 204 } & \text { EXCERPTS 5 } \\ \text { EXCURSUS 1 } & \text { EXHAUSTS 1 } & \text { EXHIBITS 16 } \\ \text { EXTERNAL 43 } & \text { EYEBROWS 9 } & \text { FIFTIETH 1 } \\ \text { FREQUENT 34 } & \text { FRUITFUL 7 } & \text { GALAXIES 7 } \\ \text { GAZETTES 1 } & \text { GNASHING 2 } & \text { HALFBACK 10 } \\ \text { HATCHWAY 2 } & \text { HEADACHE 5 } & \text { HECATOMB 1 } \\ \text { HORIZONS 6 } & \text { HUMANIZE 2 } & \text { HYACINTH 1 } \\ \text { IDLENESS 3 } & \text { IMPLYING 7 } & \text { IMPROPER 2 }\end{array}$

ABUNDANT 9

ACCOLADE 2 ADSORBED 3 AGREEING 7 AMORTIZE 2 APPROACH 123 BALLYHOO 1 BERIBERI 2 BRAZENLY 1 CHIMNEYS 3 COCKEYED 1 CONJUGAL 3 COXCOMBS 1 DISCOVER 40 DISSOLVE 6 DOWNFALL 5 EDITIONS 10 ELEVENTH 4 EQUALITY 12 EVASIONS 1 EXCHANGE 70 EXPERTLY 2 FLEXIBLE 25 GALVANIC 2 HALFWAYS 1 HEMLOCKS 1 IDENTIFY 26 INDEBTED 10 AFFINITY 5 AIRCRAFT 70 ANALYSTS 6 ARMCHAIR 4 BANKRUPT 5 BESTOWAL 4 BROCCOLI 1 CITIZENS 86 COERCIVE 2 CONJURED 2 CRUCIFIX 3 DISFAVOR 1 DIVISIVE 5 DOWNTOWN 41 EFFUSIVE 1 EMBARKED 2 EQUALZZE 1 EVENINGS 15 EXCLAIMS 1 EXPOSURE 25 FORENSIC 7 GATEWAYS 1 HARDTACK 3 HOLIDAYS 12 IDEOLOGY 13 INEXPERT 1 


\begin{tabular}{|c|c|c|c|c|}
\hline INFAMOUS 4 & INNOVATE 1 & INVALIDS 1 & INWARDLY 3 & ISOTOPIC 2 \\
\hline JACKDAWS 1 & JAPANESE 53 & JEALOUSY 4 & JEOPARDY 4 & JOLLYNG 1 \\
\hline JOURNEYS 2 & JOYFULLY 1 & JUDICIAL 16 & KERCHIEF 1 & LAVENDER 5 \\
\hline LAYERING 2 & LEUKEMIA 3 & LIBRETTO 2 & LIFELIKE 3 & LIFETTME 10 \\
\hline LIKENESS 3 & LOGISTIC 2 & LUKEWARM 5 & MACKINAW 1 & MAGAZINE 39 \\
\hline MAHOGANY 8 & MAJESTIC 10 & MANDAMUS 1 & MANEUVER 5 & MAVERICK 3 \\
\hline MAXIMUMs 2 & MIDNIGHT 23 & MYSTIQUE 5 & NARROWLY 6 & NAVIGATE 1 \\
\hline NEEDLESS 11 & NEWCOMER 7 & NEWLYWED 1 & NEWSREEL 1 & NowaDAYS 12 \\
\hline NUMBNESS 2 & OBEDIENT 2 & OFFENCES 1 & OFFERING 28 & OFFICIAL 75 \\
\hline OFFSTAGE 1 & ONLOOKER 2 & OPERATIC 5 & ORTHODOX 19 & OUTCOMES 11 \\
\hline OUTLAWRY 1 & OUTLYING 2 & OUTWEIGH 2 & OVERFLOW 2 & OVERLAPS 1 \\
\hline OVERSIZE 2 & OVERTAKE 3 & PARADIGM 6 & PARALYZE 1 & PASSERBY 1 \\
\hline PAWNSHOP 3 & PEACOCKS 4 & PELLAGRA 1 & PHYSIQUE 2 & PICAYUNE 1 \\
\hline POWERFUL 63 & PREMIUMS 2 & PREVIOUS 86 & PRIMEVAL 5 & PROBLEMS 247 \\
\hline PROHIBIT 2 & PROJECTS 68 & PROVERBS 1 & PYORRHEA 1 & QUAGMIRE 1 \\
\hline QUER YING 1 & QUIXOTIC 2 & RAINDROP 2 & RAKISHLY 1 & REBUFFED 4 \\
\hline REFLEXLY 2 & REMAKING 1 & REPRIEVE 2 & REPUBLIC 43 & RHYTHMIC 11 \\
\hline RIGHTFUL 4 & RIGIDITY 2 & ROADWAYS 1 & ROOFTOPS 1 & ROUNDUPS 1 \\
\hline SARCASMS 1 & SCHEDULE 36 & sCISsORS 1 & SEQUENCE 35 & SEXUALLY 6 \\
\hline SHADOWED 3 & SHAMEFUL 2 & SHAMROCK 3 & SHRAPNEL 2 & SHREWDLY 2 \\
\hline SHRUGGED 18 & SIDEWAYS 3 & SIGNPOST 2 & SIMPLIFY 9 & SKELETON 2 \\
\hline sKIDDING 2 & SKULLCAP 3 & SKYLIGHT 1 & SMALLPOX 2 & SOMEWHAT 127 \\
\hline SPAVINED 1 & SQUARELY 11 & SQUIRMED 2 & SQUIRREL 1 & STACCATO 5 \\
\hline s'ToICISM 5 & STRENGTH 136 & STUDYING 40 & SUBJECTS 81 & SURVIVAL 32 \\
\hline SUZERAIN 2 & sWALLOWS 2 & sWEETISH 1 & TAKEOFFS 2 & TAXPAYER 11 \\
\hline ТЕХТвООК 4 & TEXTLES 15 & THANKFUL 6 & THEORIZE 2 & THWARTED 4 \\
\hline TOGETHER 267 & TOMORROW 63 & TOWNSHIP 7 & TRANQUIL 2 & TRAPDOOR 1 \\
\hline TRIPTYCH 2 & TWILIGHT 4 & UGLINESS 7 & UNCOMMON 8 & UNDERTOW 1 \\
\hline UNGLAZED 1 & UNKNOWNS 1 & UNLAWFUL 1 & UNLIKELY 21 & UPCOMING 1 \\
\hline USEFULLY 1 & VACUUMED 1 & VAGABOND 2 & VERMOUTH 1 & VINEYARD 2 \\
\hline VOLCANIC 2 & WAKENING 1 & WALKOVER 1 & WALKWAYS 1 & WARDROBE 8 \\
\hline WASHBOWL 1 & WATCHFUL 2 & WAXWORKS 1 & WHATEVER 112 & wHIZZING 1 \\
\hline WOUNDING 1 & WRONGFUL 1 & YEARBOOK 2 & YELLOWED 1 & YOUNGISH 2 \\
\hline YOURSELF 67 & YuGosLaV 7 & ZoDIACAL 3 & & \\
\hline
\end{tabular}

